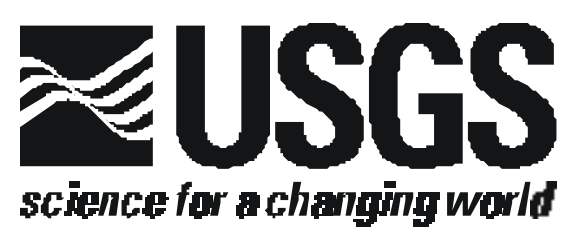

\title{
ANALYTICAL RESULTS FOR BULLION MINE AND CRYSTAL MINE WASTE SAMPLES AND BED SEDIMENTS FROM A SMALL TRIBUTARY TO JACK CREEK AND FROM UNCLE SAM GULCH, BOULDER RIVER WATERSHED, MONTANA
}

\author{
by David L. Fey ${ }^{1}$, Stanley E. Church ${ }^{1}$ and Christopher J. Finney ${ }^{1}$
}

Open-File Report 00-031

2000

On-line Edition

This report is preliminary and has not been reviewed for conformity with U.S. Geological Survey editorial standards and stratigraphic nomenclature. Any use of trade, product, or firm names is for descriptive purposes only and does not imply endorsement by the U.S. Government.

\section{U.S. DEPARTMENT OF THE INTERIOR}

\section{U.S. GEOLOGICAL SURVEY}

${ }^{1}$ Denver, Colorado 


\section{Table of Contents}

Abstract.

Figures

Figure 1. Location map of Study Area showing the Bullion Mine and Crystal Mine................ 3

Figure 2. Sample locality map for bed sediments and tailings cores ..................................... 5

Figure 3. Core sample configuration at the upper tailings impoundment, Bullion mine............. 9

Figure 4. Core sample configuration at the lower tailings impoundment, Bullion mine .............. 11

\section{Tables}

Table 1. Localities for bed-sediment sites from the Bullion and Crystal mine areas............... 8

Table 2. Localities for points where Jack Creek tributary passes through dams.................... 10

Table 3. Localities for four fluvial tailings cores from Uncle Sam Gulch................................. 12

Table 4. Element concentrations for determining depth of contamination........................... 13

Table 5. Depths and sample descriptions for cores from Bullion tailings impoundments......... 18

Table 6. Depths and sample descriptions for cores from Uncle Sam Gulch.......................... 25

Table 7. Major and trace-element data for core samples from upper tailings impoundment.... 26

Table 8. Major and trace-element data for core samples from lower tailings impoundment.... 39

Table 9. Major and trace-element data for core samples from Uncle Sam Gulch................... 48

Table 10. Major and trace-element data from total digestions of bed sediments near Bullion Mine and Crystal Mine

Table 11. Major and trace-element data from leach digestion of bed sediments near

(1)

1 Bullion Mine and Crystal Mine.
Table 12. Major and trace-element data from total digestions of leach residues of bed sediments from near Bullion and Crystal mines.....

\section{Appendix}

Table A1. Comparison of contract laboratory results with NIST values for SRM-2704........... 57

Table A2. Comparison of contract laboratory results with NIST values for SRM-2709.......... 58

Table A3. Comparison of contract laboratory results with NIST values for SRM-2711........... 59

Table A4. Comparison of USGS laboratory results with NIST values for SRM-2704............ $\quad 60$

Table A5. Comparison of USGS laboratory results with NIST values for SRM-2709.............. 61

Table A6. Comparison of USGS laboratory results with NIST values for SRM-2711 ............ 62

Table A7. ICP-AES elements and their limits of determination............................................. 63 


\begin{abstract}
Metal-mining related wastes in the Boulder River basin study area in northern Jefferson County, Montana affect water quality as a result of acid-generation and toxic-metal solubilization. Mine waste and tailings in the unnamed tributary to Jack Creek draining the Bullion mine area and in Uncle Sam Gulch below the Crystal mine are contributors to water quality degradation of Basin Creek and Cataract Creek, Montana. Basin Creek and Cataract Creek are two of three tributaries to the Boulder River in the study area. The bed sediment geochemistry in these two creeks has also been affected by the acidic drainage from these two mines. Geochemical analysis of 42 tailings cores and eleven bedsediment samples was undertaken to determine the concentrations of $\mathrm{Ag}, \mathrm{As}, \mathrm{Cd}, \mathrm{Cu}, \mathrm{Pb}$, and $\mathrm{Zn}$ present in these materials. These elements are environmentally significant, in that they can be toxic to fish and/or the invertebrate organisms in the aquatic food chain. Suites of one-inch cores of mine waste and tailings material were taken from two breached tailings impoundments near the site of the Bullion mine and from Uncle Sam Gulch below the Crystal mine. Forty-two core samples were taken and divided into 211 subsamples. The samples were analyzed by ICP-AES (inductively coupled plasmaatomic emission spectroscopy) using a mixed-acid $\left(\mathrm{HCl}-\mathrm{HNO}_{3}-\mathrm{HClO}_{4}-\mathrm{HF}\right)$ digestion. Results of the core analyses show that some samples contain moderate to very high concentrations of arsenic (as much as 13,000 ppm), silver (as much as $130 \mathrm{ppm}$ ), cadmium (as much as $260 \mathrm{ppm}$ ), copper (as much as 9,000 ppm), lead (as much as 11,000 ppm), and zinc (as much as 18,000 ppm). Eleven bed-sediment samples were also subjected to the mixed-acid total digestion, and a warm $\left(50^{\circ} \mathrm{C}\right) 2 \mathrm{M} \mathrm{HCl}-1 \% \mathrm{H}_{2} \mathrm{O}_{2}$ leach and analyzed by ICP-AES. Results indicate that bed sediments of the Jack Creek tributary are impacted by past mining at the Bullion and Crystal mines. The contaminating metals are mostly contained in the $2 \mathrm{M} \mathrm{HCl}-1 \% \mathrm{H}_{2} \mathrm{O}_{2}$ leachable phase, which are the hydrous amorphous iron- and manganese-hydroxide coatings on detrital sediment particles.
\end{abstract}




\section{INTRODUCTION}

Metal-mining related wastes in the Boulder River basin study area (fig. 1) in northern Jefferson County, Montana potentially affect water quality as a result of acid generation and toxic-metal solubilization during snow melt and storm water runoff events (Buxton and others, 1997). The bed sediments and waters of an unnamed tributary of Jack Creek have been impacted by contamination from mine waste and tailings from the Bullion mine and mill complex. This contamination also affects Jack Creek, which is a tributary to Basin Creek (Metesh and others, 1994). Similarly, waste material from the Crystal Mine, located on the east side of Jack Mountain from the Bullion mine, has been deposited in Uncle Sam Gulch. Uncle Sam Gulch is a tributary to Cataract Creek; both Basin Creek and Cataract Creek are major tributaries to the Boulder River in the study area (see fig. 1), and are contributors to water quality degradation of the Boulder River.

The Bullion Mine was worked periodically between 1897 and 1955; it was the largest and most productive of the inactive mines in the Basin Mining District. In 1929, a flotation mill was built at the mine site. The mined ore contained pyrite, tetrahedrite, galena, sphalerite, arsenopyrite, quartz, and siderite (Metesh and others, 1994). The mine and associated waste rock and development rock dumps, and the mill and its associated tailings are situated mostly on private land. However, there are two breached tailings impoundments below the mill on the Jack Creek tributary; most of the upper impoundment and the entire lower impoundment are located on Deerlodge National Forest land. These impoundments straddle the creek, and provide a continuous source of contamination to the creek. Tailings have been transported downstream to the confluence with Jack Creek.

The Crystal Mine was worked from 1908 through the 1960's and produced ore from veins of the same mineralized east-west shear zone as the Bullion Mine. Mineralized or ore-bearing veins of the Crystal Mine contain pyrite, arsenopyrite, galena, chalcopyrite, tetrahedrite, covellite, and chalcocite (Metesh and others, 1995). The Crystal Mine is also on private land, but waste material deposited in Uncle Sam Gulch is located on Deerlodge National Forest land.

Desborough and Fey (1997) studied waste material from nine mine sites in the Basin district and produced a qualitative scale for potential water-quality degradation resulting from these mine wastes. The scale was based on the combined weights of acid-generation potential, dissolved toxic metals from a passive leach, and estimated tonnage. At the Bullion Mine site, waste material from three mine dumps located on the hill above the mill and creek scored seven, eight, and nine on a scale of one (low) to nine (high). By comparison, material from the two breached tailings impoundments below the Bullion Mine complex scored a moderate four and five on the same scale. However, since this material lies directly in or next to the creek, these tailings have a more immediate effect on water quality. These two tailings impoundments on the Jack Creek tributary and a small reach of fluvially-deposited waste in Uncle Sam Gulch are the subject of this investigation. This report presents analytical results for total-digestion elemental content for 42 cores, nine bed sediments and bed-sediment leach residues, and leachable elemental content for the nine bed sediments as released by a warm $\left(50^{\circ} \mathrm{C}\right) 2 \mathrm{M} \mathrm{HCl}-1$ percent $\mathrm{H}_{2} \mathrm{O}_{2}$ digestion. Similar reports covered the fluvial tailings present in High Ore Creek below the Comet Mine

(Fey and Church, 1998) and flotation tailings present in and near 

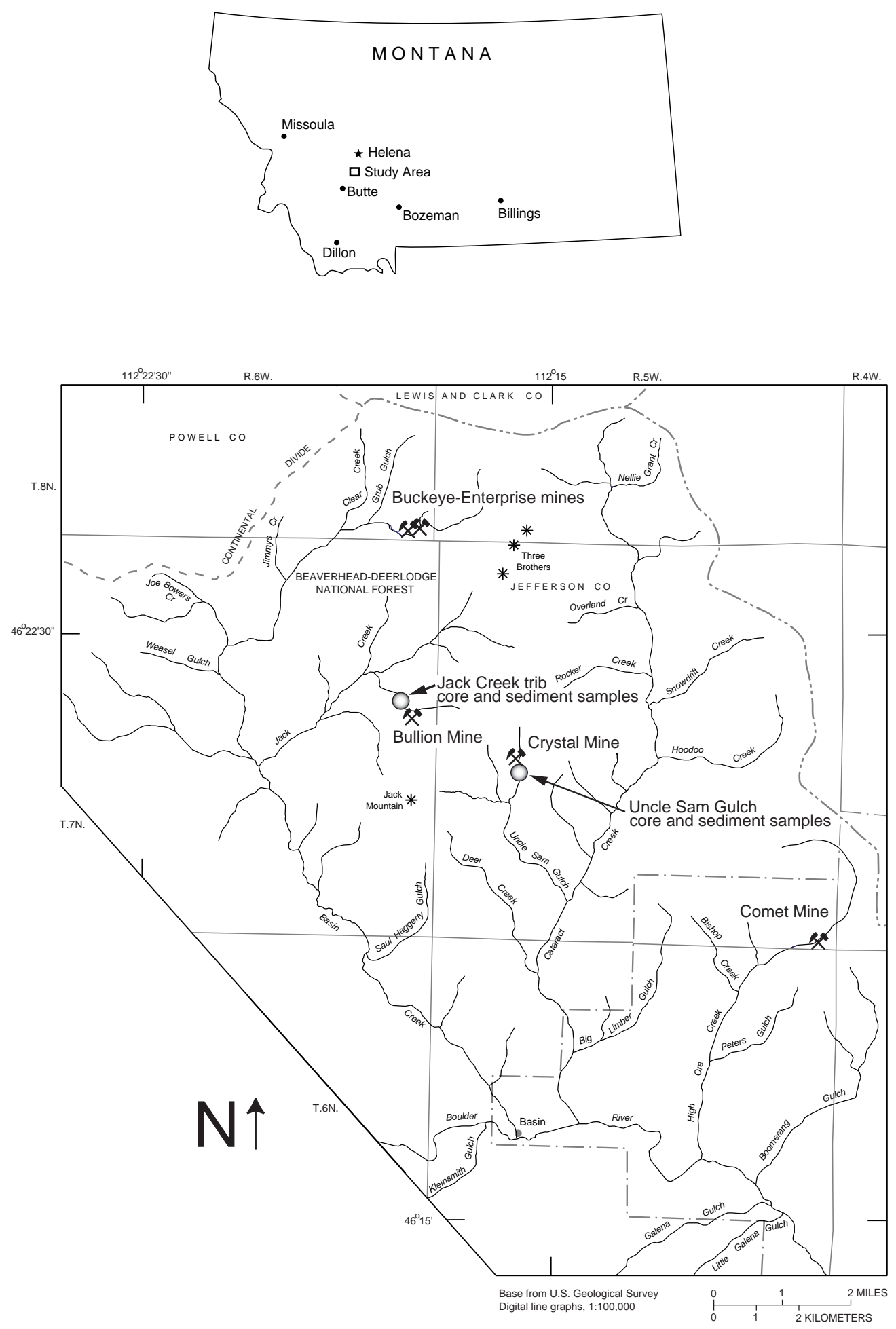

Figure 1. Index map of Montana showing Boulder River study area and sample localities for mill-tailings cores and bed sediments along tributary of Jack Creek below Bullion Mine, and sample localities for mine-waste cores and bed sediments along Uncle Sam Gulch below Crystal Mine. 
the floodplain of Basin Creek at the Buckeye-Enterprise mines and mill complex (fig. 1) (Fey and others, 1999).

\section{METHODS OF STUDY}

\section{Sample collection}

Core and sediment samples were collected from a small, unnamed tributary of Jack Creek, which flows from the Bullion Mine area (T7N, R6W, Section 13) north to Jack Creek, and from Uncle Sam Gulch above and below the Crystal Mine area (T7N, R5W, Section 20). All sample sites are located on the Basin, Montana USGS 1:24,000 topographic map.

Bed sediments

In October 1996, we collected 47 bed-sediment samples in the Boulder River basin, including one from the unnamed Jack Creek tributary and one from Jack Creek just below its confluence with that tributary. In July 1997, we collected four additional bed-sediment samples from the same tributary, from above the mine development area down to near the confluence with Jack Creek, and a second sample from Jack Creek below the tributary. In July 1998, we collected a third sample at that same site. In October 1996, we collected two bed-sediment samples from Uncle Sam Gulch, both below the Crystal mine site. In July 1997, we collected two additional sediments from Uncle Sam Gulch, one above the Crystal mine and one below. See figure 2 for the localities of the bed-sediment samples.

Analyses of bed-sediment samples represent the geochemistry of material eroded upstream of the sample site and from colloidal material coating the detrital grains. An integrated bed-sediment sample was collected at each site by compositing 10 to 20 individual subsites within $15 \mathrm{~m}(50 \mathrm{ft})$ of the plotted sample locality, collecting material from the active channel alluvium. In the field, each composited sample was sieved through a $2 \mathrm{~mm}$ (10-mesh) stainless-steel screen, and the minus- $2 \mathrm{~mm}$ fraction retained; the larger size fractions were discarded.

\section{Tailings Cores}

In July 1997, we collected a suite of 23 one-inch diameter cores from the upper tailings impoundment area (not the active stream channel) downstream from the Bullion Mine. This sample suite is identified as 97-BMF-102. Farther downstream at the lower tailings impoundment area, we collected a suite of 15 cores; this suite is identified as 97-BMF-103. Along Uncle Sam Gulch below the Crystal mine, we collected four one-inch diameter cores of fluvially deposited mine waste; these samples are identified as 97-BMF-109. See figure 2 for the site localities of the core-sample suites.

All samples were collected in plastic core tubes using a stainless-steel soil probe/sampler. Most cores were driven to depths up to $65 \mathrm{~cm}$, the maximum penetration of a single probe. However, at favorable sites, a probe extension was used to collect a second core from below the depth of the first core, with a maximum penetration of $130 \mathrm{~cm}$. Core penetration depth and actual core length were recorded on-site to determine the amount of compression. 


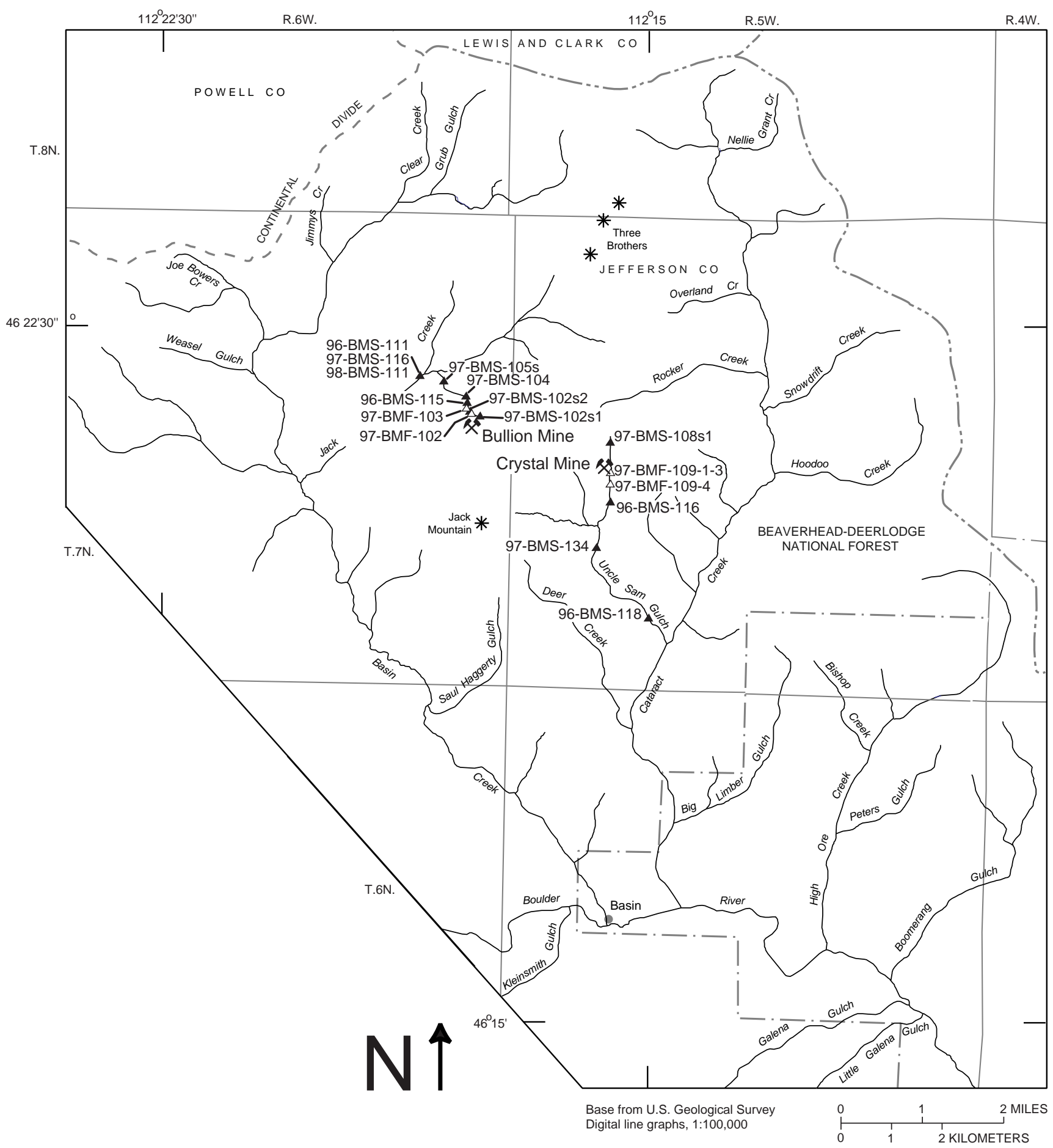

Figure 2. Sample locality map for bed sediments ( $\mathbf{\Lambda}$ )and mine-waste core samples $(\Delta)$ from the Bullion and Crystal Mine areas. 


\section{Sample Preparation}

Bed-sediment Samples

Bed-sediment samples were dried at ambient room temperature $\left(25^{\circ} \mathrm{C}\right)$ and sieved to minus80 -mesh $(<0.18 \mathrm{~mm})$ prior to laboratory analyses.

\section{Tailings Cores}

Core samples were subdivided in the laboratory into subsamples (by depth) according to visual identification of differences in color, mineralogy, organic content, and presence of iron oxide coloring. A core compression factor was calculated and used to determine the actual depth of the subsamples; the assigned depth for each is defined as the midpoint of that subsample. The cores were divided into two to thirteen subsamples, typically about five or six. These subsamples were then placed in a random order and ground using a vertical pulverizer with ceramic plates to minus 100 -mesh $(<0.15 \mathrm{~mm})$. The 23 cores from the upper impoundment (97-BMF-102) were subdivided into 124 subsamples, and the 15 cores from the lower impoundment (97-BMF-103) were subdivided into 74 subsamples. The four cores from Uncle Sam Gulch were subdivided into 13 subsamples.

\section{Sample Analysis}

Total-digestion Inductively Coupled Plasma-Atomic Emission Spectroscopy (ICP-AES) analysis for 33 elements

The ten bed-sediment samples, leach residues from partial extractions (described below) of the ten sediment samples, and 211 core subsamples were digested with a mixed-acid procedure consisting of $\mathrm{HCl}, \mathrm{HNO}_{3}, \mathrm{HClO}_{4}$, and $\mathrm{HF}$, and analyzed for 33 elements by ICP-AES (Crock and others, 1983; Briggs, 1996). This procedure dissolves most minerals, including silicates, oxides and sulfides; resistant or refractory minerals such as zircon, chromite, and some tin oxides are only partially dissolved. Previous investigations using a variety of geologic materials confirm the completeness of the digestion (Church and others, 1987; Wilson and others, 1994).

The core sample analyses were performed by a contract laboratory using the prescribed procedure. The values for total-digestion analyses for the core samples are given in table 7 and table 8 (Bullion mine-tailings impoundments), and table 9 (Uncle Sam Gulch below Crystal Mine). The analyses of the stream sediments and their leach residues were performed at the USGS laboratories in Denver, using the same chemical digestion procedure. The concentrations for total-digestion analyses of the bed sediments are given in table 10, and the concentrations for the total-digestion analyses of the bed-sediment leach residues are given in table 12. Limits of determination for the total digestion method are given in table A7 in the Appendix. Comparisons of values observed for three National Institute of Standards and Technology (NIST) standard reference materials (SRM-2704, SRM-2709 and SRM2711) with certified values (NIST, 1993a, 1993b, and 1993c) are given in table A1, table A2, and table A3 (contract laboratory) and table A4, table A5, and table A6 (USGS laboratory) in the Appendix. 
Warm 2M HCl-1percent $\mathrm{H}_{2} \mathrm{O}_{2}$ leach extraction

The use of a partial-digestion extraction enables one to determine concentrations of trace elements bound within different phases, whereas a total digestion releases all trace elements in a sample (Chao, 1984). The ten bed sediments from the Jack Creek tributary and Uncle Sam Gulch were subjected to a partial-digestion extraction consisting of warm $\left(50^{\circ} \mathrm{C}\right) 2 \mathrm{M} \mathrm{HCl}-1$ percent $\mathrm{H}_{2} \mathrm{O}_{2}$ for three hours with continuous agitation in USGS laboratories; the leachates were subsequently analyzed by ICP-AES for 29 elements. This partial extraction releases trace elements associated with hydrous amorphous iron- and manganese-oxide mineral coatings and colloidal particles (Appendix III of Church and others, 1993; Church and others, 1997). Mineral coatings such as those observed in Jack Creek can contain a significant portion of the trace elements in a sample (Church and others, 1997). The residues from this extraction were then dried, weighed, and subjected to the total digestion described above to determine trace element concentrations bound in the oxide, silicate, and more-resistant sulfide phases. The data obtained from the $2 \mathrm{M} \mathrm{HCl}-1$ percent $\mathrm{H}_{2} \mathrm{O}_{2}$ extraction are presented in table 11 . Analytical limits of determination for the partial-digestion leach method are given in table A7 in the Appendix.

\section{Site descriptions}

Bullion Mine area bed sediments

Four bed-sediment samples were taken from the unnamed tributary that flows from above the Bullion Mine to its confluence with Jack Creek. The uppermost one (97-BMS-102S1) was collected above any influence from the mine waste, tailings, or draining water (fig.2). The next sediment sample (97-BMS-102S2) was collected about $200 \mathrm{~m}$ (650 ft) downstream from 97-BMS-102S1, and about $120 \mathrm{~m}$ (400 ft) below the upper of two breached tailings impoundment dams. The next sample, 96BM-115, was collected about $150 \mathrm{~m}$ (500 ft) downstream of 97-BMS-102S2; it is about $60 \mathrm{~m} \mathrm{(200}$ $\mathrm{ft}$ ) below the lower of the two breached tailings impoundments. The lowest bed-sediment sample from the tributary, 97-BMS-105S, was collected about $700 \mathrm{~m}(2,300 \mathrm{ft})$ below 96-BM-115. This sample is about $270 \mathrm{~m}(900 \mathrm{ft})$ above the confluence of this tributary with Jack Creek. About $300 \mathrm{~m}(1,000 \mathrm{ft})$ below this confluence is a former beaver dam that impounded tailings on Jack Creek; this beaver dam has also been breached. We took a bed-sediment sample from Jack Creek at a site just below the beaver dam in 1996, 1997, and 1998. These samples are labeled 96-BM-111, 97-BMS-116, and 98-BMS-111. The purpose of taking replicate sediment samples from the same site was to assess the annual variation in trace element content. Sample sites were plotted in the field on the USGS 1:24,000 Basin topographic map; table 1 gives the localities of the bed-sediments for samples from the Bullion mine area.

Crystal Mine area bed sediments

Four bed-sediment samples from Uncle Sam Gulch are included in this report. The uppermost sample, 97-BMS-108S1, was taken about $0.8 \mathrm{~km}$ (0.5 mi.) upstream from the Crystal Mine (fig. 2), above the influence from mine waste, tailings, or drainage. The second sample, 96-BM-116, was taken about $0.5 \mathrm{~km}(0.3 \mathrm{MI})$ downstream from the Crystal mine. The third sample, 97-BMS-134, was taken about $1.5 \mathrm{~km}$ (0.9 MI.) downstream from the mine. The fourth bed-sediment sample (96-BM-118) on 
Uncle Sam Gulch was taken about $0.7 \mathrm{~km}(0.4 \mathrm{mi}$.) upstream from the confluence with Cataract Creek. Table 1 gives the localities of the bed sediments from Uncle Sam Gulch.

Table 1. Localities of bed-sediment sites from the Bullion mine and Crystal mine areas.

\begin{tabular}{l|lll|}
\cline { 2 - 4 } & \multicolumn{1}{|c|}{ Sample Site } & $\begin{array}{c}\text { Latitude } \\
\text { (DMS) }\end{array}$ & \multicolumn{1}{c|}{$\begin{array}{c}\text { Longitude } \\
\text { (DMS) }\end{array}$} \\
\cline { 2 - 4 } & $\begin{array}{l}\text { (D)-BMS-102s1 } \\
46^{\circ} 21^{\prime} 26.2^{\prime \prime}\end{array}$ & $112^{\circ} 17^{\prime} 40.8^{\prime \prime}$ \\
Bullion area & $97-B M S-102 s 2$ & $46^{\circ} 21^{\prime} 29.5^{\prime \prime}$ & $112^{\circ} 17^{\prime} 47.8^{\prime \prime}$ \\
bed sediments & $96-B M S-115$ & $46^{\circ} 21^{\prime} 33.8^{\prime \prime}$ & $112^{\circ} 17^{\prime} 48.6^{\prime \prime}$ \\
(Jack Creek and trib) & $97-B M S-105 S$ & $46^{\circ} 21^{\prime} 47.1^{\prime \prime}$ & $112^{\circ} 18^{\prime} 11.7^{\prime \prime}$ \\
& $97-B M S-116$ & $46^{\circ} 21^{\prime} 52.4^{\prime \prime}$ & $112^{\circ} 18^{\prime} 32.4^{\prime \prime}$ \\
& $96-B M S-111$ & $46^{\circ} 21^{\prime} 52.4^{\prime \prime}$ & $112^{\circ} 18^{\prime} 32.4^{\prime \prime}$ \\
& $98-B M S-111$ & $46^{\circ} 21^{\prime} 52.4^{\prime \prime}$ & $112^{\circ} 18^{\prime} 32.4^{\prime \prime}$ \\
Crystal area & & & \\
bed sediments & $97-B M S-108 s 1$ & $46^{\circ} 21^{\prime} 16.9^{\prime \prime}$ & $112^{\circ} 15^{\prime} 36.7^{\prime \prime}$ \\
(Uncle Sam Gulch) & $96-B M S-116$ & $46^{\circ} 20^{\prime} 37.7^{\prime \prime}$ & $112^{\circ} 15^{\prime} 37.3^{\prime \prime}$ \\
& $97-B M S-134$ & $46^{\circ} 20^{\prime} 02.8^{\prime \prime}$ & $112^{\circ} 15^{\prime} 47.9^{\prime \prime}$ \\
& $96-B M S-118$ & $46^{\circ} 19^{\prime} 21.0^{\prime \prime}$ & $112^{\circ} 15^{\prime} 00.0^{\prime \prime}$ \\
\hline
\end{tabular}

Bullion Mine area tailings cores

\section{Upper tailings impoundment}

One-inch diameter core suites were collected from two breached tailings impoundments located on the Jack Creek tributary. Below the former millsite at the main mine development area, a moderately steep, logged slope extends down to the creek and towards the upper impoundment dam. The dam, built about 1930 (Rossilon and Haynes, 1999), was constructed of tailings material; subsequently, the dam was breached, and tailings were transported down the creek. The dam is about $40 \mathrm{~m}(130 \mathrm{ft})$ wide, $5 \mathrm{~m}(16 \mathrm{ft})$ thick at the base, and $2.5 \mathrm{~m}(8 \mathrm{ft})$ tall. There are still tailings present on both banks of the creek, and the active channel continues to cut through the tailings, eroding and transporting tailings material downstream We ran a traverse line from the southern half of the tailings

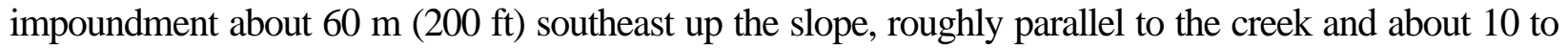
$15 \mathrm{~m}$ (30 to $45 \mathrm{ft}$ ) southwest of it. The bearing of the traverse line was S $52^{0} \mathrm{E}$. We collected core samples along the traverse labeled 97-BMF-102 (fig. 3). Core samples were taken from sites 1, 4, 5, 6,7 , and 8 (97-BMF-102-4, -5, -6, -7, and -8) at regular $5 \mathrm{~m}$ spacing. No core was taken at either site 2 or 3 (fig. 3), because the material was loose, unconsolidated sand and peat, and would not stay in the collection tube. Sample 97-BMF-102-9 was collected $7 \mathrm{~m}(23 \mathrm{ft})$ from 97-BMF-102-8, and sample 97-BMF-102-10 was collected $8 \mathrm{~m}$ (27 ft) down from -102-9. Sample 97-BMF-102-10 was taken from an isolated lens of tailings material that was formerly contiguous with the southern half of the impoundment. Samples above this site (southeast) were of material that was a mixture of mine waste, soil, peat, and wood. The last core sample of the main traverse, 97-BMF-102-11, was collected from southeast side of the impoundment dam.

We collected core samples from two additional traverses, one across the top of the impoundment dam, perpendicular to the main traverse, and one along the north half of the 


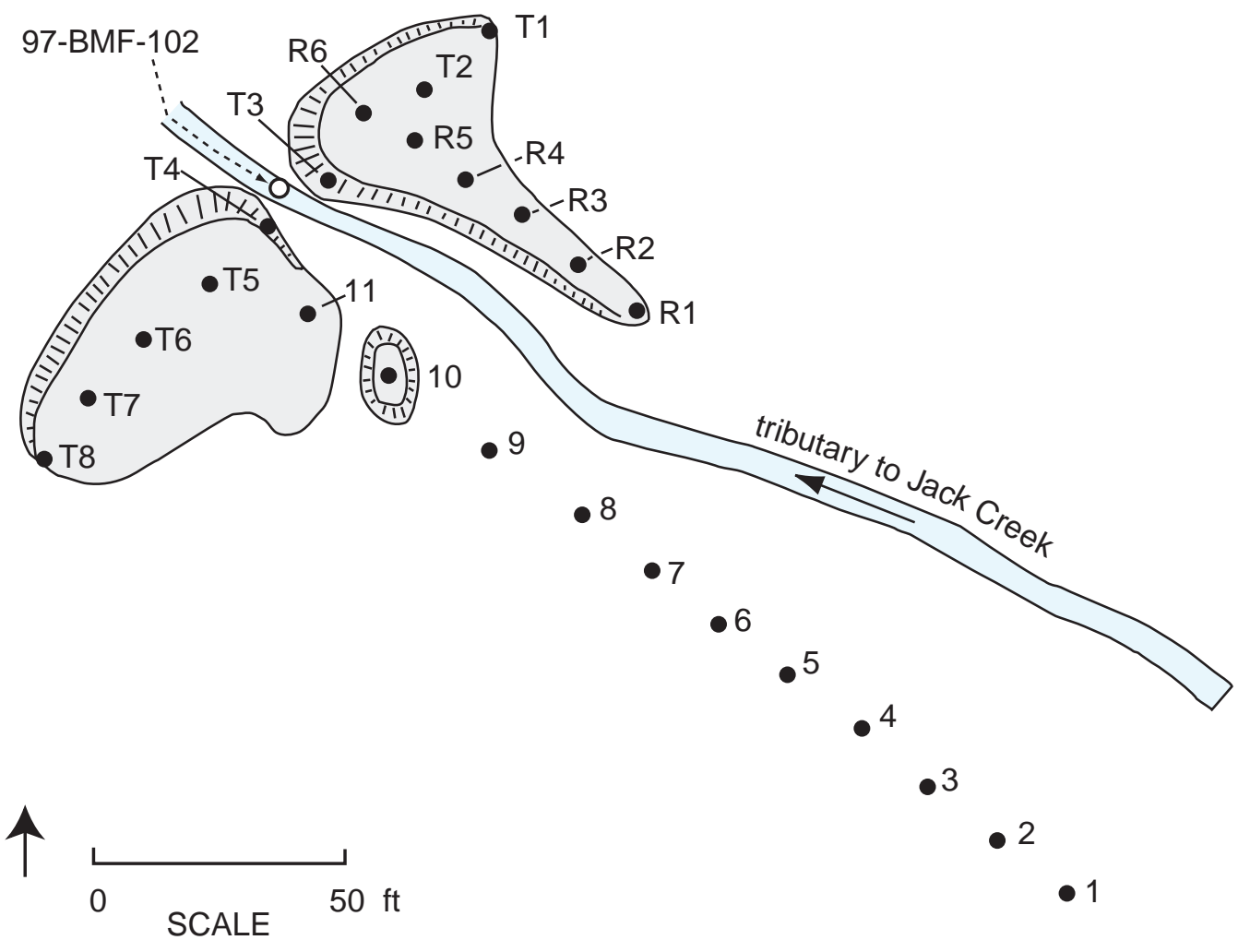

Figure 3. Sample configuration map for tailings cores taken at 97-BMF-102, upper tailings impoundment at Bullion Mine 
dissected impoundment, parallel to the main traverse (fig. 3). The end traverse (samples labeled 97BMF-102-T1 through T8) was started at the northeast corner of the impoundment dam, where the forest soil began, and ran southwest, on a bearing of $\mathrm{S}^{\circ} \mathrm{W}$, across the creek and to the other side, ending at the edge of the southwest corner of the dam. The sites were unevenly spaced because of the interruption caused by the breach, the stream, and debris close to the stream. The unnamed tributary runs between sample sites 97-BMF-102-T3 and -T4. The localities of the core sites are not presented in the tables because the relative positions were determined by compass and tape, and are best presented in figure 3 and figure 4 . However, the locality of the point where the tributary passes through the breached dam can accurately be determined from aerial photographs. Table 2 gives the localities of the points where the tributary passes through the two breached dams. Finally, we collected cores from a traverse along the north half of the tailings impoundment. This traverse started about $30 \mathrm{~m} \mathrm{(100} \mathrm{ft)}$ southeast of the face of the impoundment dam, and ran above and along the bank of the creek. Six core samples were taken from this tailings bank at regular spacing intervals of $5 \mathrm{~m}$. These are labeled 97-BMF-102-R1 through -R6 (fig. 3).

Table 2. Localities of points where Jack Creek tributary passes through breached dams

\begin{tabular}{|ccc|}
\hline Sample Site & $\begin{array}{c}\text { Latitude } \\
\text { (DMS) }\end{array}$ & $\begin{array}{c}\text { Longitude } \\
\text { (DMS) }\end{array}$ \\
\hline \hline 97-BMF-102 & $46^{\circ} 21^{\prime} 28.0^{\prime \prime}$ & $112^{\circ} 17^{\prime} 46.0^{\prime \prime}$ \\
$97-B M F-103$ & $46^{\circ} 21^{\prime} 30.5^{\prime \prime}$ & $112^{\circ} 17^{\prime} 48.5^{\prime \prime}$ \\
\hline
\end{tabular}

\section{Lower tailings impoundment}

About $100 \mathrm{~m}$ (330 ft) downstream from the first breached impoundment dam is a second tailings impoundment dam, which is also breached. This lower dam is about $1.5 \mathrm{~m}(5 \mathrm{ft})$ tall, $5 \mathrm{~m}$ (16 ft) thick at the base, and $75 \mathrm{~m}(250 \mathrm{ft})$ wide, and was constructed of rock and dirt fill; the dam itself contained no tailings. We collected core samples from this impoundment from three separate traverses. The main traverse samples are labeled 97-BMF-103-T1 through -103-T9 (fig. 4). The sample line had a bearing of $\mathrm{N} 60^{\circ} \mathrm{E}$ and was located parallel to the dam top and about $5 \mathrm{~m}(16 \mathrm{ft})$ upstream. Core sample 97-BMF-103-T1 was taken from the southwest end of the traverse, and subsequent samples were taken at $10 \mathrm{~m}$ spacing (33 ft) for samples -103-T2 through -103-T6. Sample number 97-BMF103-T7 was located $57 \mathrm{~m}$ (190 ft) northeast of 97-BMF-103-T1; sample number 97-BMF-103-T8 was $67 \mathrm{~m}(220 \mathrm{ft})$, and 97-BMF-103-T9 was $73 \mathrm{~m}$ (240 ft) from 97-BMF-103-T1. The unnamed tributary runs between samples -103-T6 and -103-T7; Table 2 gives the locality of where the tributary passes through the breached dam.

We collected core samples from two longitudinal traverses, the first starting at sample site 97BMF-103-T4 and running perpendicular to the dam and up through the tailings material. This line produced three samples. The first, 97-BMF-103-L1, was located $5 \mathrm{~m}$ (16 ft) up (southeast) of the main traverse line. Samples 97-BMF-103-L2 and -L3 were located 10 and $15 \mathrm{~m}$ up from the main line, respectively. Along this longitudinal traverse, at a distance of $18 \mathrm{~m}$ (60 ft) up from the main traverse line, only a thin veneer of tailings is present, and at $20 \mathrm{~m}(65 \mathrm{ft})$ there are no tailings. 


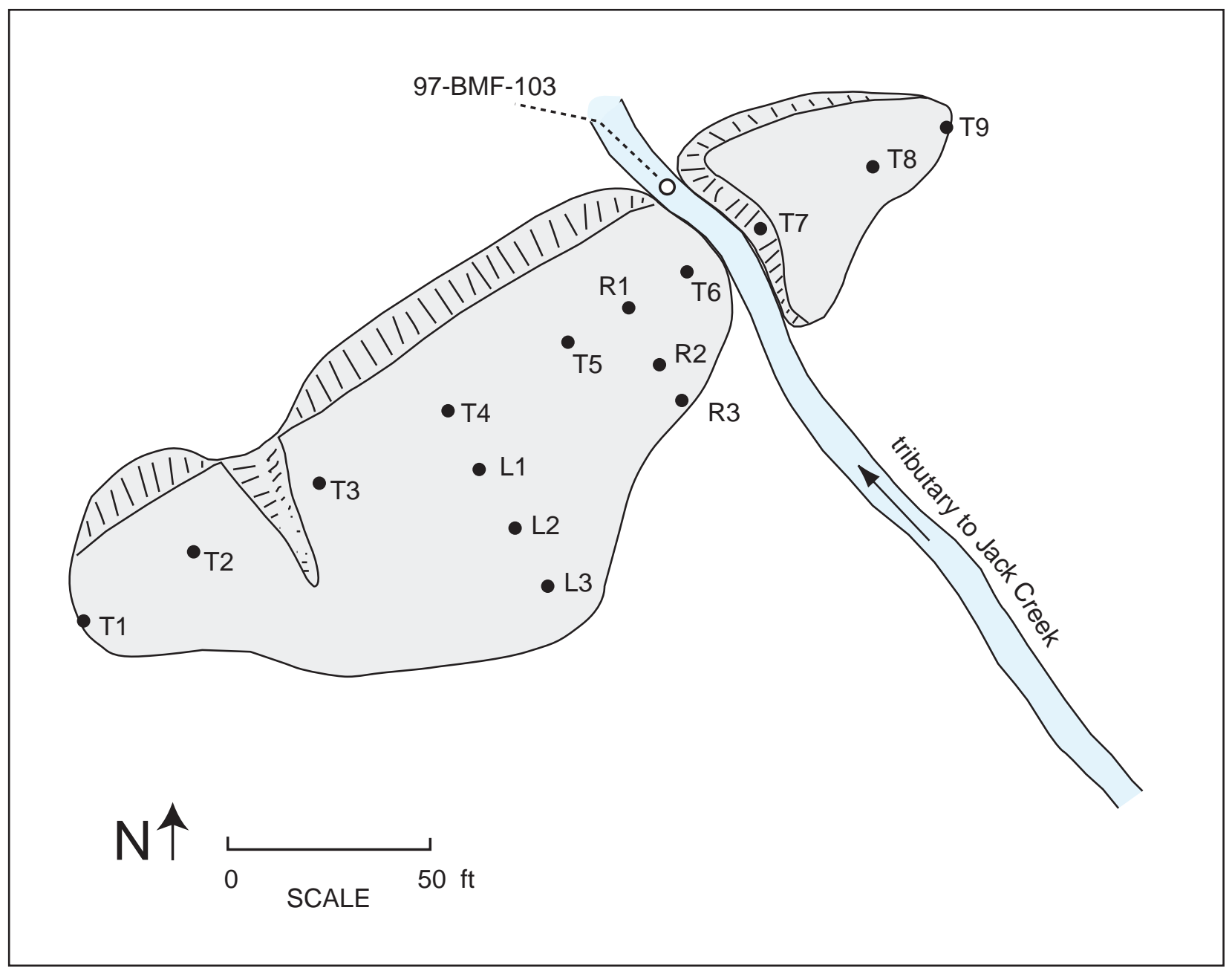

Figure 3. Sample configuration map for tailings cores taken at 97-BMF-103, lower tailings impoundment at Bullion Mine. 
The second longitudinal traverse was started from the main traverse line between samples 97-BMF103-T5 and -T6 (fig. 4.) The first sample, 97-BMF-103-R1, was collected from where the main

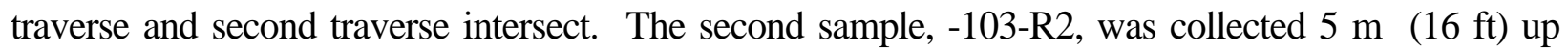

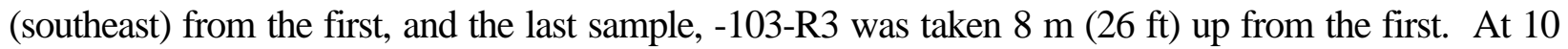
$\mathrm{m}(33 \mathrm{ft})$ along the second traverse line, there are no tailings present.

Crystal Mine area fluvial tailings cores

Mine waste and tailings from the Crystal Mine have been eroded into the creek in Uncle Sam Gulch. This material is then incorporated into the bed sediments and transported downstream. We took four different one-inch cores from Uncle Sam Gulch downstream of the Crystal Mine. Uncle Sam Gulch in this area is steep and narrow, with an active channel of about 3 to $4 \mathrm{~m}$ (10 to $13 \mathrm{ft}$ ). There are numerous downed logs in the creek channel which create pockets where sediment has accumulated. The first three cores, 97-BMF-109-1 through -109-3, were collected from the creek about $100 \mathrm{~m}$

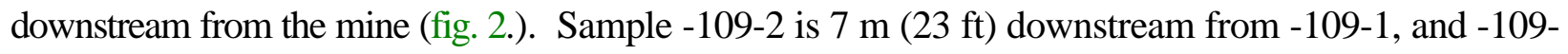
3 is $10 \mathrm{~m}$ (33 ft) downstream from -109-1. Below the third sample, the sediment deposits are discontinuous. The fourth sample, 97-BMF-109-4, was taken from an isolated sediment deposit about $230 \mathrm{~m}(750 \mathrm{ft})$ downstream from 97-BMF-109-3. Table 3 gives the localities of the fluvial tailings cores from Uncle Sam Gulch.

Table 3. Localities of four fluvial tailings cores from Uncle Sam Gulch below Crystal mine

\begin{tabular}{l|ccc|}
\cline { 2 - 4 } & Sample Site & $\begin{array}{c}\text { Latitude } \\
\text { (DMS) }\end{array}$ & $\begin{array}{c}\text { Longitude } \\
\text { (DMS) }\end{array}$ \\
\cline { 2 - 4 } Uncle Sam Gulch & $97-B M F-109-1$ & $46^{\circ} 20^{\prime} 49.5^{\prime \prime}$ & $112^{\circ} 15^{\prime} 36.5^{\prime \prime}$ \\
fluvial tailings cores & $97-B M F-109-2$ & $46^{\circ} 20^{\prime} 49.3^{\prime \prime}$ & $112^{\circ} 15^{\prime} 36.5^{\prime \prime}$ \\
& $97-B M F-109-3$ & $46^{\circ} 20^{\prime} 49.2^{\prime \prime}$ & $112^{\circ} 15^{\prime} 36.5^{\prime \prime}$ \\
$97-B M F-109-4$ & $46^{\circ} 20^{\prime} 42.0^{\prime \prime}$ & $112^{\circ} 15^{\prime} 36.5^{\prime \prime}$ \\
\hline
\end{tabular}

\section{Discussion of Results}

Mine-waste cores

\section{Bullion mine upper impoundment}

Examination of the analytical data (table 7) indicates that the majority of core samples contain contamination from the environmentally important elements $\mathrm{Ag}, \mathrm{As}, \mathrm{Cd}, \mathrm{Cu}, \mathrm{Pb}$, and $\mathrm{Zn}$. Along the main traverse (97-BMF-102-1 through -11), the maximum concentrations for the elements listed above are: 110 ppm silver, 6,600 ppm arsenic, 250 ppm cadmium, 9,000 ppm copper, 6,500 ppm lead, and $18,000 \mathrm{ppm}$ zinc $(1.8 \%)$. Along traverse $\mathrm{R}$, the maximum concentrations for the elements listed above are: 76 ppm silver, 6,800 ppm arsenic, 34 ppm cadmium, 930 ppm copper, 7,800 ppm lead, and 500 ppm zinc. Along traverse T, the maximum concentrations for the elements listed above are: $120 \mathrm{ppm}$ silver, 11,000 ppm arsenic (1.1\%), 56 ppm cadmium, 2,300 ppm copper, 6,500 ppm lead, and 770 ppm zinc. In a report on the mill tailings present at Buckeye Meadow, Fey and others (1999) used operationally defined cutoff values for five elements $(\mathrm{Ag}, \mathrm{Cd}, \mathrm{Cu}, \mathrm{Pb}$, and $\mathrm{Zn}$ ) to determine the depths 
at which cores penetrated through mine waste and associated deeper contamination related to downward metal migration. These values are shown in table 4. However, application of these cutoff values to cores from the Bullion mine area was not possible, because the cores typically were not deep enough to penetrate through to uncontaminated material; analytical results from the cores did not show contaminant-element concentrations approach the cutoff values with depth. The depths of penetration for the cores along the main traverse of the upper impoundment did not exceed $60 \mathrm{~cm}(2 \mathrm{ft})$, and thus the analytical results indicate that the total depths of contamination were greater than $60 \mathrm{~cm}$ along the entire line of cores. Four cores from the upper impoundment exceeded $60 \mathrm{~cm}$ in depth: 97- BMF102-R5, -R6, -T7, and -T8; their penetrations were 77, 76, 126, and $97 \mathrm{~cm}$, respectively. None of these cores penetrated to below the contaminated material. Only one core, 97-BMF-102-R1, penetrated below contamination; this core was taken from the southeast end of the north half of the impoundment, where the tailings grade into forest soil.

Table 4. Element concentrations used for determining depth of contamination at Buckeye Meadow, upper Basin Creek (from Fey and others, 1999)

\begin{tabular}{|lc|}
\hline \multicolumn{1}{|c|}{ Element } & Cutoff (ppm) \\
\hline \hline Silver & 5 \\
Cadmium & 5 \\
Copper & 300 \\
Lead & 100 \\
Zinc & 500 \\
\hline
\end{tabular}

The data do show a difference in metal content between the material on the slope southeast of the upper impoundment (cores 97-BMF-102-1 through -10) and the actual tailings of the impoundment. The concentrations of zinc from cores along the main traverse before the impoundment tailings are higher (maximum concentration of 18,000 ppm) and more variable than from the tailings themselves (maximum concentration of $770 \mathrm{ppm}$ ). The same is true for copper (maximum concentration of 9,000 ppm from slope above tailings; maximum concentration of 2,300 ppm from tailings themselves). The opposite is true for lead: concentrations in the impoundment tailings are much higher (maximum concentration of 7,800 ppm) and more variable than concentrations along the main traverse line (maximum concentration of $3,800 \mathrm{ppm}$ ). The silver concentrations are higher and more variable in the impoundment tailings than from the slope above the tailings. Arsenic values are high and variable for all cores. Average cadmium concentrations show no great distinction between the cores from the slope and the cores from the impoundment tailings.

\section{Bullion Mine lower impoundment}

The analytical data from the lower impoundment cores (table 8) also show high concentrations of $\mathrm{Ag}, \mathrm{As}, \mathrm{Cd}, \mathrm{Cu}, \mathrm{Pb}$, and $\mathrm{Zn}$. Along the transverse traverse (97-BMF-103-T1 through -T9), the maximum concentrations for the elements listed above are: 90 ppm silver, 7,300 ppm arsenic, $39 \mathrm{ppm}$ cadmium, 2,500 ppm copper, 6,500 ppm lead, and $640 \mathrm{ppm}$ zinc. Along traverse $\mathrm{R}$, the maximum concentrations for the elements listed above are: $130 \mathrm{ppm}$ silver, 12,000 ppm arsenic (1.2\%), $68 \mathrm{ppm}$ cadmium, 1,000 ppm copper, 7,700 ppm lead, and $310 \mathrm{ppm}$ zinc. Along traverse L, the maximum concentrations for the elements listed above are: $110 \mathrm{ppm}$ silver, 13,000 ppm arsenic (1.3\%), $31 \mathrm{ppm}$ 
cadmium, 520 ppm copper, 16,000 ppm lead (1.6\%), and $280 \mathrm{ppm}$ zinc. Only two cores from the lower impoundment penetrated below the tailings. One was core 97-BMF-103-R3, taken from within two meters of the edge of the tailings upstream from the dam, and the other was 97-BMF-103-T5.

\section{Uncle Sam Gulch cores}

The data for the cores taken below the Crystal Mine along Uncle Sam Gulch are shown in table 9. These cores are also contaminated with the elements discussed above. The maximum concentrations from the four cores are: $26 \mathrm{ppm}$ silver, $11,000 \mathrm{ppm}$ arsenic (1.1\%), $110 \mathrm{ppm}$ cadmium, 1,600 ppm copper, 2,300 ppm lead, and 8,000 ppm zinc. These cores are from small, discontinuous lenses of sediment in Uncle Sam Gulch.

Bed sediments

The contrast in trace-element content between bed-sediment samples from above and below the two mines is shown by the total-digest data in table 10. Regional background values, determined from our unpublished work in the Boulder study area, are: silver, less than 2 ppm; cadmium, less than 2 ppm: copper, $30 \mathrm{ppm}$; lead $55 \mathrm{ppm}$; and zinc, $170 \mathrm{ppm}$. Both bed-sediment samples taken from above the respective mines (97-BMS-102S1 above the Bullion Mine and 97-BMS-108S1 above the Crystal Mine) have concentrations similar to these regional background values. The concentrations increase markedly below the two mine sites. For example, at the Bullion Mine tributary to Jack Creek, arsenic concentrations in bed sediments increase from $45 \mathrm{ppm}$ (upstream) to 2,300 ppm (first sediment sample downstream). Copper increases from $47 \mathrm{ppm}$ to $320 \mathrm{ppm}$, lead increases from $59 \mathrm{ppm}$ to 870 ppm, and zinc increases from $240 \mathrm{ppm}$ to $690 \mathrm{ppm}$. Along Uncle Sam Gulch, similar increases occur below the Crystal Mine. Arsenic concentrations increase from $39 \mathrm{ppm}$ (upstream) to 3,600 ppm (first sediment sample downstream), copper increases from $36 \mathrm{ppm}$ to $560 \mathrm{ppm}$, lead increases from 34 ppm to $1,900 \mathrm{ppm}$, and zinc increases from $160 \mathrm{ppm}$ to $920 \mathrm{ppm}$

Analyses of trace elements from the warm $2 \mathrm{M} \mathrm{HCl}-1 \% \mathrm{H}_{2} \mathrm{O}_{2}$ leach (table 11) show that much of the trace-element content in the bed sediments is in the leachable phase. This partial extraction releases metals associated with hydrous amorphous iron- and manganese-oxide coatings and colloidal particles incorporated into the bed sediments (Church and others, 1997). The extraction solution only weakly attacks primary sulfide grains with the exception of galena $(\mathrm{PbS})$, which is readily soluble in warm $2 \mathrm{M} \mathrm{HCl}$. The proportions of leachable to total concentrations for the metals reveal information about the mineral phases containing and transporting the different metals in the bed sediments.

Examination of the individual elements from the six bed sediments reveals the following:

1. Silver in the leachable phase from the Jack Creek tributary (Bullion Mine) and from Uncle Sam Gulch (Crystal Mine) comprises 70 percent to 100 percent of the total.

2. Arsenic in the leachable phase from the Jack Creek tributary (Bullion Mine) and from Uncle Sam Gulch (Crystal mine) comprises 70 percent to 100 percent of the total.

3. Cadmium in the leachable phase from the Jack Creek tributary comprises 40 percent to 100 percent of the total and from Uncle Sam Gulch comprises 80 percent to 100 percent of the total.

4. Copper in the leachable phase from the Jack Creek tributary comprises 60 percent to 100 percent of the total and from Uncle Sam Gulch comprises 45 percent to 100 percent of the total. 
5. Lead in the leachable phase from the Jack Creek tributary (Bullion Mine) and from Uncle Sam Gulch (Crystal Mine) comprises 80 percent to 100 percent of the total (although since the leach solution solubilizes primary galena, one cannot differentiate between primary- mineral lead and sorbed lead.

6. Zinc in the leachable phase from the Jack Creek tributary comprises 40 percent to 100 percent of the total and from Uncle Sam Gulch comprises 7 percent to 100 percent of the total zinc.

The leach data of the bed sediments reflect the process of element sorption onto colloids and iron- and manganese-hydroxides, and subsequent settling and incorporation into bed sediments. This process helps describe element transport in bed sediments downstream, as discussed in Church and others (1997). A striking example of this is the case of copper and zinc in sample 96-BMS-118. This sample is the farthest downstream from the Crystal Mine on Uncle Sam Gulch, and yet the copper and zinc concentrations are greater than samples collected proximal to the mine. The copper and zinc are sorbed onto colloids and/or iron- and manganese-hydroxides, which are carried in suspension in the water column until they settle out in stream reaches with lower gradients. At the site of 96-BMS-118, the gradient of Uncle Sam Gulch is lower than above, and so the suspended material has accumulated in the bed sediments. The leach data show that 100 percent of the copper and 97 percent of the zinc in this sample are contained in the leachable phase.

\section{Summary and Conclusions}

Analytical results for 23 cores collected from above the upper tailings impoundment below the Bullion Mine, 15 cores from the lower tailings impoundment, and four cores from Uncle Sam Gulch below the Crystal Mine reveal that six environmentally important trace elements (Ag, $\mathrm{As}, \mathrm{Cd}, \mathrm{Cu}, \mathrm{Pb}$ and $\mathrm{Zn}$ ) are present at high concentrations. Analyses of eleven bed sediments from the Jack Creek tributary and from Uncle Sam Gulch show significant influence from mine waste and tailings. Partial extractions of the bed sediments reveal that a significant fraction ( 40 percent to 100 percent) of these named trace elements are present in phases dissolved by a warm $2 \mathrm{M} \mathrm{HCl}-1$ percent $\mathrm{H}_{2} \mathrm{O}_{2}$ leach. These leachable phases include settled colloids and hydrous amorphous iron- and manganese-hydroxide coatings of bed-sediment particles. 


\section{REFERENCES CITED}

Briggs, P.H., 1996, Forty elements by inductively coupled-plasma atomic emission spectrometry, in Arbogast, B.F., ed., Analytical methods manual for the Mineral Resources Program: U.S. Geological Survey Open-File Report 96-525, p. 77-94.

Buxton, H.T., Nimick, D.A., von Guerard, P., Church, S.E., Frazier, A., Gray, J.R., Lipin, B.R., Marsh, S.P. Woodward, D., Kimball, B., Finger, S., Ischinger, L., Fordham, J.C., Power, M.S., Bunck, C., and Jones, J.W., 1997, A science-based Watershed strategy to support effective remediation of abandoned mine lands: in Fourth International Conference on Acid Rock Drainage Proceedings, v. IV, Vancouver, B.C. Canada, May 31-June 5, 1997, p. $1869-1880$.

Chao, T.T., 1984, Use of partial dissolution techniques in geochemical exploration: Journal of Geochemical Exploration, v. 20, p. 101-135.

Church, S.E., Mosier, E.L., and Motooka, J.M., 1987, Mineralogical basis for the interpretation of multielement (ICP-AES), oxalic acid, and aqua-regia partial digestions of stream sediments for reconnaissance exploration geochemistry: Journal of Geochemical Exploration, v. 29, p. 207-233.

Church, S.E., Holmes, C.E., Briggs, P.H., Vaughn, R.B., Cathcart, James and Marot, Margaret, 1993, Geochemical and lead-isotope data from stream and lake sediments, and cores from the upper Arkansas River drainage: Effects of mining at Leadville Colorado on heavymetal concentrations in the Arkansas River: U.S. Geological Survey Open-File Report 93-534, $61 \mathrm{p}$.

Church, S.E., Kimball, B.A., Fey, D.L., Ferderer, D.A., Yager, T.J., and Vaughn, R.B., 1997, Source, transport, and partitioning of metals between water, colloids, and bed sediments of the Animas River, Colorado: U.S. Geological Survey Open-File Report 97-151, 135 p.

Crock, J.G., Lichte, F.E., and Briggs, 1983, Determination of elements in National Bureau of Standards geologic reference materials SRM 278 obsidian and SRM 688 basalt by inductively coupled plasma-atomic emission spectroscopy: Geostandards Newsletter, v. 7, p. 335-340.

Desborough , G.A., and Fey, D.L., 1997, Preliminary characterization of acid-generating potential and toxic metal solubility of some abandoned metal-mining related wastes in the Boulder River headwaters, northern Jefferson County, Montana: U.S. Geological Survey Open File Report 97-478, $21 \mathrm{p}$.

Fey, D.L., and Church, S.E., 1998. Analytical results for 42 fluvial tailings cores and 7 stream sediment samples from High Ore Creek, northern Jefferson County, Montana: U.S. Geological Survey Open File Report 98-215, 49 p.

Fey, D.L., Church, S.E., and Finney, C.J., 1999. Analytical resultsf for 35 mine-waste tailings cores and six bed-sediment samples, and an estimate of the volume of contaminated material at Buckeye meadow on upper Basin Creek, northern Jefferson County, Montana: U.S. Geological Survey Open File Report 99-537, 59 p. 
Metesh, J., Lonn, J., Duaime, T., and Wintergerst, R., 1994, Abandoned-inactive mines program Deer Lodge National Forest, Volume I-Basin Creek Drainage: Montana Bureau of Mines and Geology Open-File Report 321, 131 p.

Metesh, J., Lonn, J., Duaime, T., Marvin, R., and Wintergerst, R., 1995, Abandoned-inactive mines program, Deer Lodge National Forest, Volume II-Cataract Creek Drainage: Montana Bureau of Mines and Geology Open-File Report 321, 202 p.

National Institute of Standards and Technology (NIST), 1993a, Certificate of Analysis Standard Reference Material 2704, Buffalo River Sediment. , 1993b, Certificate of Analysis Standard Reference Material 2709, San Joaquin Soil. , 1993c, Certificate of Analysis Standard Reference Material 2711, Montana Soil.

Rossillon, M. and Haynes, T., 1999, Basin Creek Mine Reclamation Heritage Resource Inventory 1998 [Report for the Beaverhead-Deerlodge National Forest, U.S. Forest Service, Dillon, Montana.]: Renewable Technologies, Inc., Butte, Montana, v.1 126 p., v.2 Appendices.

Wilson, S. A., Briggs, P.H., Mee, J.S., and Siems, D.F., 1994, Determinations of thirty-two major and trace elements in three NIST soil SRMs using ICP-AES and WDXRF: Geostandards Newsletter, v. 18, p. 85-89. 
Appendix

Discussion of results in tables A1 through A6

The ICP-AES analyses of the core samples were done by an outside laboratory; the analyses of the bed-sediment samples were done in-house in the USGS laboratories in Denver, Colorado. The results from the contract laboratory are generally acceptable, but there are several notable exceptions. The recoveries were somewhat less accurate, and the variances were higher for samples run by the contract laboratory than for those run by the USGS laboratory. Arsenic is biased high below $100 \mathrm{ppm}$, and somewhat low above $100 \mathrm{ppm}$, relative to recommended NIST values. No recommendations are presented to normalize these analyses; at the high As levels contained in the cores, the values are acceptable. Cobalt is biased low, but is not an important element in this study. Chromium recoveries are very low, due to incomplete digestion, and we do not recommend using the chromium analyses. Lead shows a high bias at levels below $50 \mathrm{ppm}$, is relatively neutral at several hundred ppm, and shows a low bias at levels greater than 1,000 ppm. The analyses are still quite acceptable for the purpose of this report. The values for titanium from both laboratories tend to be low, due to the refractory nature of titanium oxides, which may not be completely dissolved in this acid digestion. 
TABLE A1 Comparison of contract laboratory results with NIST values for SRM-2704

\begin{tabular}{|c|c|c|c|c|c|}
\hline SRM-2704 & $\mathrm{n}=20$ & & & & \\
\hline Element & $\begin{array}{r}\text { observed } \\
\text { conc. }\end{array}$ & $\begin{array}{r}\text { observed } \\
\% \text { RSD }\end{array}$ & $\begin{array}{l}\text { NIST } \\
\text { value }\end{array}$ & $\begin{array}{l}\text { NIST } \\
\text { C.I.* }\end{array}$ & $\begin{array}{r}\text { PERCENT } \\
\text { RECOVERY }\end{array}$ \\
\hline Al \% & 5.71 & 2.8 & 6.11 & 0.16 & 93 \\
\hline $\mathrm{Ca} \%$ & 2.61 & 5.6 & 2.6 & 0.03 & 100 \\
\hline $\mathrm{Fe} \%$ & 3.73 & 3.9 & 4.11 & 0.10 & 91 \\
\hline K \% & 1.84 & 4.9 & 2.00 & 0.04 & 92 \\
\hline $\mathrm{Mg} \%$ & 1.12 & 3.3 & 1.2 & 0.02 & 93 \\
\hline $\mathrm{Na} \%$ & 0.56 & 4.8 & 0.55 & 0.014 & 102 \\
\hline P \% & 0.08 & 8.1 & 0.099 & 0.003 & 81 \\
\hline $\mathrm{Ti} \%$ & 0.33 & 5.3 & 0.457 & 0.018 & 72 \\
\hline $\mathrm{Mn}, \mathrm{ppm}$ & 550 & 4.3 & 555 & 19 & 99 \\
\hline $\mathrm{Ag}, \mathrm{ppm}$ & $<2$ & -- & -- & -- & -- \\
\hline As, ppm & 33.6 & 60 & 23.4 & 0.8 & 144 \\
\hline $\mathrm{Ba}, \mathrm{ppm}$ & 405 & 14 & 414 & 12 & 98 \\
\hline $\mathrm{Cd}, \mathrm{ppm}$ & $<2$ & -- & 3.45 & 0.22 & - \\
\hline $\mathrm{Ce}, \mathrm{ppm}$ & 62 & 3.7 & 72 & -- & 86 \\
\hline Co, ppm & 10.9 & 0.7 & 14 & 0.6 & 78 \\
\hline Cr, ppm & 76.6 & 20 & 135 & 5 & 57 \\
\hline $\mathrm{Cu}, \mathrm{ppm}$ & 88.9 & 5.5 & 98.6 & 5 & 90 \\
\hline Ga, ppm & 10.9 & 3.5 & 15 & -- & 73 \\
\hline La, ppm & 29.2 & 0.8 & 29 & -- & 101 \\
\hline $\mathrm{Li}, \mathrm{ppm}$ & 39.5 & 1.3 & 50 & -- & 79 \\
\hline Mo, ppm & 3.6 & 0.5 & -- & -- & --1 \\
\hline $\mathrm{Nb}, \mathrm{ppm}$ & 6.2 & 3.8 & -- & -- & -- \\
\hline $\mathrm{Nd}, \mathrm{ppm}$ & 28.9 & 1.3 & -- & -- & -- \\
\hline $\mathrm{Ni}$, ppm & 38.4 & 1.8 & 44 & 3 & 87 \\
\hline $\mathrm{Pb}, \mathrm{ppm}$ & 161 & 20 & 161 & 17 & 100 \\
\hline Sc, ppm & 10.6 & 0.5 & 12 & -- & 88 \\
\hline Sr, ppm & 125 & 4.5 & 130 & -- & 96 \\
\hline Th, ppm & 7.4 & 2 & 9.2 & -- & 80 \\
\hline V, ppm & 88.4 & 9.8 & 95 & 4 & 93 \\
\hline $\mathrm{Y}, \mathrm{ppm}$ & 18.9 & 0.9 & -- & -- & -- \\
\hline Yb, ppm & 2.1 & 0.3 & 2.8 & -- & 75 \\
\hline $\mathrm{Zn}, \mathrm{ppm}$ & 375 & 22 & 438 & 12 & 86 \\
\hline
\end{tabular}

* $95 \%$ confidence interval

This table shows the results for twenty analyses for SRM-2704 submitted as blind samples to the contract laboratory. 
TABLE A2 Comparison of contract laboratory results with NIST values for SRM-2709

\begin{tabular}{|c|c|c|c|c|c|}
\hline SRM-2709 & $\mathrm{n}=20$ & & & & \\
\hline & observed & observed & NIST & NIST & PERCENT \\
\hline Element & conc. & $\%$ RSD & value & C.I. ${ }^{*}$ & RECOVERY \\
\hline Al $\%$ & 7.02 & 3.4 & 7.5 & 0.06 & 94 \\
\hline $\mathrm{Ca} \%$ & 1.82 & 3.4 & 1.89 & 0.05 & 96 \\
\hline $\mathrm{Fe} \%$ & 3.26 & 3.4 & 3.50 & 0.11 & 93 \\
\hline K \% & 1.89 & 5.3 & 2.03 & 0.06 & 93 \\
\hline $\mathrm{Mg} \%$ & 1.41 & 5.1 & 1.51 & 0.05 & 93 \\
\hline $\mathrm{Na} \%$ & 1.11 & 6.5 & 1.16 & 0.03 & 96 \\
\hline$P \quad \%$ & 0.05 & 11 & 0.062 & 0.005 & 81 \\
\hline $\mathrm{Ti} \%$ & 0.35 & 2.8 & 0.342 & 0.024 & 102 \\
\hline $\mathrm{Mn}, \mathrm{ppm}$ & 482 & 4.80 & 538 & 17 & 90 \\
\hline $\mathrm{Ag}, \mathrm{ppm}$ & $<2$ & -- & 0.41 & 0.03 & - \\
\hline As, ppm & 27.7 & 14 & 17.7 & 0.8 & 156 \\
\hline $\mathrm{Ba}, \mathrm{ppm}$ & 903 & 24 & 968 & 40 & 93 \\
\hline $\mathrm{Cd}, \mathrm{ppm}$ & $<2$ & -- & 0.38 & 0.01 & - \\
\hline $\mathrm{Ce}, \mathrm{ppm}$ & 42.6 & 2.1 & 42 & -- & 101 \\
\hline Co, ppm & 10.6 & 0.7 & 13.4 & 0.7 & 79 \\
\hline Cr, ppm & 41.2 & 16 & 130 & 4 & 32 \\
\hline $\mathrm{Cu}, \mathrm{ppm}$ & 30.1 & 1.3 & 34.6 & 0.7 & 87 \\
\hline $\mathrm{Ga}, \mathrm{ppm}$ & 14.2 & -- & 14 & -- & 101 \\
\hline La, ppm & 21.7 & 1.2 & 23 & -- & 94 \\
\hline $\mathrm{Li}, \mathrm{ppm}$ & 47.5 & 1.3 & 50 & -- & 95 \\
\hline Mo, ppm & $<2$ & -- & 2 & -- & -- \\
\hline $\mathrm{Nb}, \mathrm{ppm}$ & 8.1 & 4.6 & -- & -- & - \\
\hline $\mathrm{Nd}, \mathrm{ppm}$ & 18.5 & 0.7 & 19 & -- & 97 \\
\hline $\mathrm{Ni}, \mathrm{ppm}$ & 72.5 & 2.5 & 88 & 5 & 82 \\
\hline $\mathrm{Pb}, \mathrm{ppm}$ & 30 & 12 & 18.9 & 0.5 & 159 \\
\hline Sc, ppm & 11 & 0.3 & 12 & -- & 92 \\
\hline $\mathrm{Sr}, \mathrm{ppm}$ & 215 & 7.8 & 231 & 2 & 93 \\
\hline Th, ppm & 9.8 & 0.8 & 11 & -- & 89 \\
\hline $\mathrm{V}, \quad \mathrm{ppm}$ & 108 & 8.3 & 112 & 5 & 96 \\
\hline $\mathrm{Y}, \mathrm{ppm}$ & 13.4 & 0.5 & 18 & -- & 74 \\
\hline Yb, ppm & 1.8 & 0.2 & 1.6 & -- & 113 \\
\hline Zn, ppm & 95.6 & 8.6 & 106 & 3 & 90 \\
\hline
\end{tabular}

* $95 \%$ confidence interval

This table shows the results for twenty analyses for SRM-2709 submitted as blind samples to the contract laboratory. 
TABLE A3 Comparison of contract laboratory results with NIST values for SRM-2711

\begin{tabular}{|c|c|c|c|c|c|}
\hline SRM-2711 & $n=20$ & & & & \\
\hline Element & $\begin{array}{r}\text { observed } \\
\text { conc. }\end{array}$ & $\begin{array}{r}\text { observed } \\
\% \text { RSD }\end{array}$ & $\begin{array}{l}\text { NIST } \\
\text { value }\end{array}$ & $\begin{array}{l}\text { NIST } \\
\text { C.I. }{ }^{*}\end{array}$ & $\begin{array}{r}\text { PERCENT } \\
\text { RECOVERY }\end{array}$ \\
\hline Al $\%$ & 6.33 & 2.79 & 6.53 & 0.09 & 97 \\
\hline $\mathrm{Ca} \%$ & 2.81 & 3.73 & 2.88 & 0.08 & 98 \\
\hline $\mathrm{Fe} \%$ & 2.70 & 1.75 & 2.89 & 0.06 & 93 \\
\hline K \% & 2.34 & 4.76 & 2.45 & 0.08 & 95 \\
\hline $\mathrm{Mg} \mathrm{\%}$ & 0.99 & 3.62 & 1.05 & 0.03 & 94 \\
\hline $\mathrm{Na} \%$ & 1.16 & 4.30 & 1.14 & 0.03 & 101 \\
\hline P \% & 0.07 & 9.59 & 0.086 & 0.007 & 83 \\
\hline $\mathrm{Ti} \%$ & 0.29 & 1.69 & 0.306 & 0.023 & 96 \\
\hline $\mathrm{Mn}, \mathrm{ppm}$ & 575 & 4.1 & 638 & 28 & 90 \\
\hline $\mathrm{Ag}, \mathrm{ppm}$ & 4.5 & 15 & 4.63 & 0.39 & 97 \\
\hline As, ppm & 93.8 & 13 & 105 & 8 & 89 \\
\hline $\mathrm{Ba}, \mathrm{ppm}$ & 747 & 21 & 726 & 38 & 103 \\
\hline $\mathrm{Cd}, \mathrm{ppm}$ & 34.6 & 4.9 & 41.7 & 0.25 & 83 \\
\hline $\mathrm{Ce}, \mathrm{ppm}$ & 70 & 6.6 & 69 & -- & 101 \\
\hline Co, ppm & 8 & 8.3 & 10 & -- & 80 \\
\hline $\mathrm{Cr}, \mathrm{ppm}$ & 18.1 & 34 & 47 & -- & 39 \\
\hline $\mathrm{Cu}, \mathrm{ppm}$ & 106 & 5.6 & 114 & 2 & 93 \\
\hline $\mathrm{Ga}, \mathrm{ppm}$ & 13.7 & 18 & 15 & -- & 91 \\
\hline La, ppm & 37.2 & 4.7 & 40 & -- & 93 \\
\hline $\mathrm{Li}, \quad$ ppm & 24.1 & 4.1 & -- & -- & - \\
\hline Mo, ppm & $<2$ & -- & -- & -- & - \\
\hline $\mathrm{Nb}, \mathrm{ppm}$ & 15 & 21 & -- & -- & - \\
\hline $\mathrm{Nd}, \mathrm{ppm}$ & 31.1 & 2.9 & 31 & -- & 100 \\
\hline $\mathrm{Ni}, \mathrm{ppm}$ & 17.8 & 4 & 20.6 & 1.1 & 86 \\
\hline $\mathrm{Pb}, \mathrm{ppm}$ & 1060 & 3.8 & 1162 & 31 & 91 \\
\hline Sc, ppm & 8.8 & 4.2 & 9 & -- & 98 \\
\hline $\mathrm{Sr}, \mathrm{ppm}$ & 236 & 2.3 & 245 & 0.7 & 96 \\
\hline Th, ppm & 12.1 & 12 & 14 & -- & 86 \\
\hline V, ppm & 79.4 & 7.9 & 81.6 & 2.9 & 97 \\
\hline Y, ppm & 23 & 4.3 & 25 & -- & 92 \\
\hline $\mathrm{Yb}, \mathrm{ppm}$ & 2.9 & 11 & 2.7 & -- & 107 \\
\hline Zn, ppm & 304 & 3.9 & 350 & 4.8 & 87 \\
\hline
\end{tabular}

* $95 \%$ confidence interval

This table shows the results for twenty analyses for SRM-2711 submitted as blind samples to the contract laboratory. 
TABLE A4 Comparison of USGS laboratory results with NIST values for SRM-2704

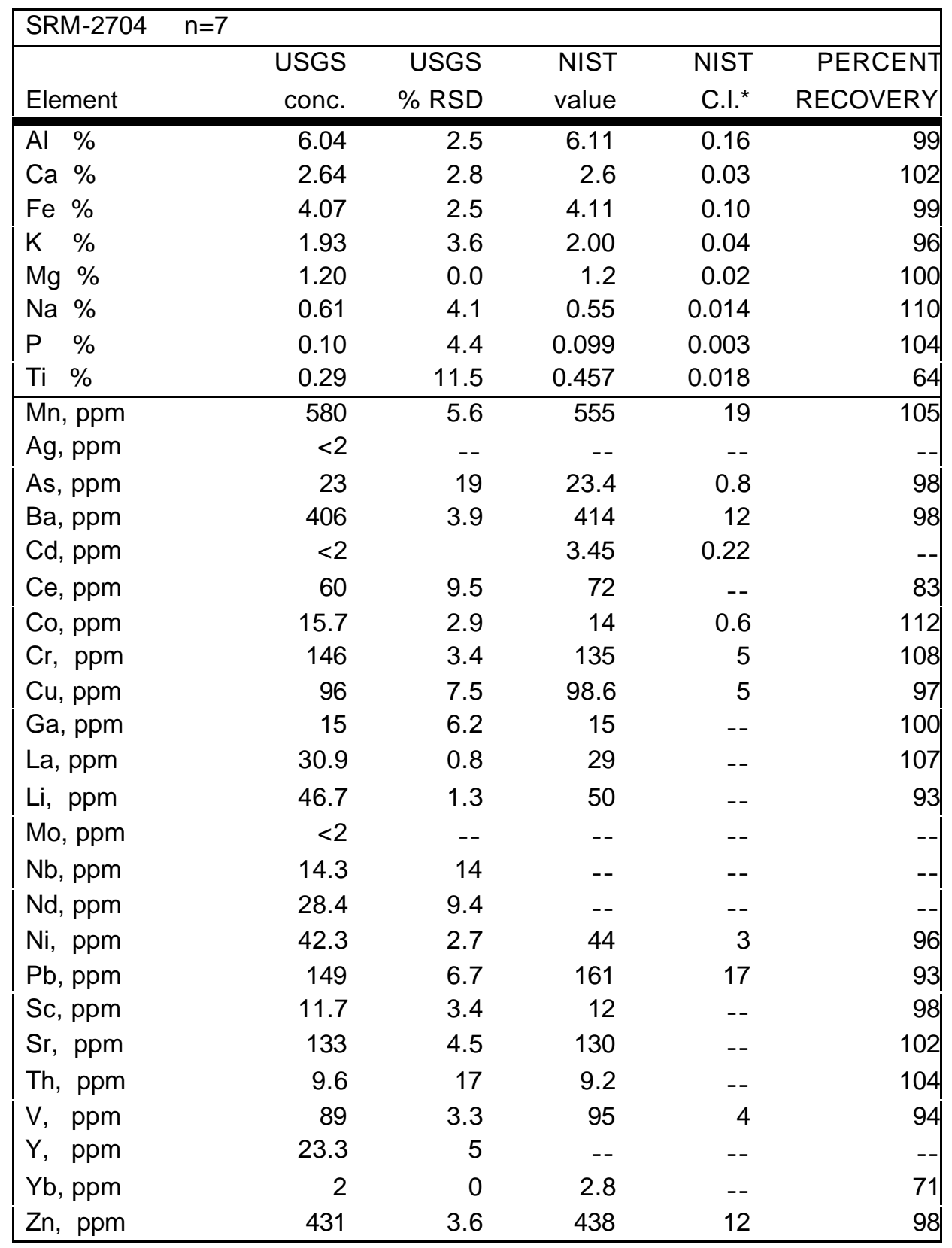

* $95 \%$ confidence interval

This table shows the results for seven analyses for SRM-2704 analyzed in-house in the USGS analytical laboratories in Denver, Co. 
TABLE A5 Comparison of USGS laboratory results with NIST values for SRM-2709

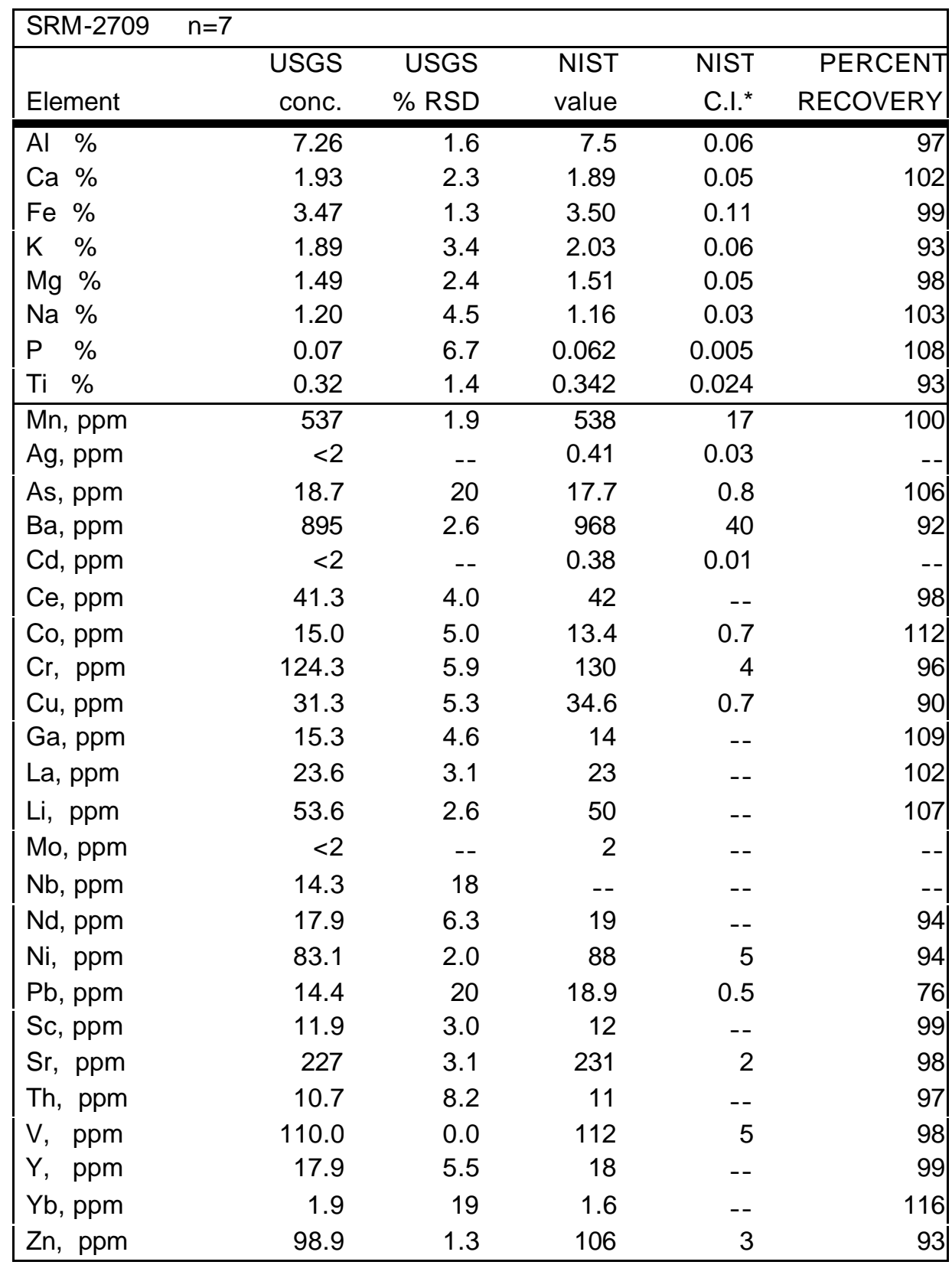

* $95 \%$ confidence interval

This table shows the results for seven analyses for SRM-2709 analyzed in-house in the USGS analytical laboratories in Denver, Co. 
TABLE A6 Comparison of USGS laboratory results with NIST values for SRM-2711

\begin{tabular}{|c|c|c|c|c|c|}
\hline SRM-2711 & $n=7$ & & & & \\
\hline Element & $\begin{array}{l}\text { USGS } \\
\text { conc. }\end{array}$ & $\begin{array}{l}\text { USGS } \\
\% \text { RSD }\end{array}$ & $\begin{array}{l}\text { NIST } \\
\text { value }\end{array}$ & $\begin{array}{l}\text { NIST } \\
\text { C.I. }{ }^{*}\end{array}$ & $\begin{array}{r}\text { PERCENT } \\
\text { RECOVERY }\end{array}$ \\
\hline $\mathrm{Al} \quad \%$ & 6.39 & 3.3 & 6.53 & 0.09 & 98 \\
\hline $\mathrm{Ca} \%$ & 2.93 & 3.5 & 2.88 & 0.08 & 102 \\
\hline $\mathrm{Fe} \%$ & 2.86 & 3.2 & 2.89 & 0.06 & 99 \\
\hline K \% & 2.34 & 6.0 & 2.45 & 0.08 & 96 \\
\hline $\mathrm{Mg} \%$ & 1.04 & 4.7 & 1.05 & 0.03 & 99 \\
\hline $\mathrm{Na} \%$ & 1.21 & 5.3 & 1.14 & 0.03 & 107 \\
\hline P \% & 0.08 & 5.9 & 0.086 & 0.007 & 98 \\
\hline Ti \% & 0.26 & 3.5 & 0.306 & 0.023 & 84 \\
\hline $\mathrm{Mn}, \mathrm{ppm}$ & 677 & 14 & 638 & 28 & 106 \\
\hline $\mathrm{Ag}, \mathrm{ppm}$ & 3.6 & 14 & 4.63 & 0.39 & 77 \\
\hline As, ppm & 100 & 6.6 & 105 & 8 & 95 \\
\hline $\mathrm{Ba}, \mathrm{ppm}$ & 688 & 4.7 & 726 & 38 & 95 \\
\hline $\mathrm{Cd}, \mathrm{ppm}$ & 37.3 & 1.9 & 41.7 & 0.25 & 89 \\
\hline Ce, ppm & 67.4 & 4.1 & 69 & -- & 98 \\
\hline Co, ppm & 11.6 & 4.3 & 10 & -- & 116 \\
\hline $\mathrm{Cr}, \mathrm{ppm}$ & 47.0 & 3.4 & 47 & -- & 100 \\
\hline $\mathrm{Cu}, \mathrm{ppm}$ & 108 & 6.5 & 114 & 2 & 95 \\
\hline $\mathrm{Ga}, \mathrm{ppm}$ & 16.0 & 6.7 & 15 & -- & 107 \\
\hline La, ppm & 37.9 & 3.8 & 40 & -- & 95 \\
\hline Li, ppm & 26.7 & 4.8 & -- & -- & -- \\
\hline Mo, ppm & $<2$ & -- & -- & -- & -- \\
\hline $\mathrm{Nb}, \mathrm{ppm}$ & 17.0 & 31 & -- & -- & -- \\
\hline $\mathrm{Nd}, \mathrm{ppm}$ & 28.9 & 4.3 & 31 & -- & 93 \\
\hline $\mathrm{Ni}, \quad$ ppm & 19.6 & 2.5 & 20.6 & 1.1 & 95 \\
\hline $\mathrm{Pb}, \mathrm{ppm}$ & 1070 & 6.7 & 1162 & 31 & 92 \\
\hline Sc, ppm & 9.3 & 4.9 & 9 & -- & 103 \\
\hline $\mathrm{Sr}, \mathrm{ppm}$ & 244 & 3.7 & 245 & 0.7 & 100 \\
\hline Th, ppm & 13.9 & 4.6 & 14 & -- & 99 \\
\hline V, ppm & 77.6 & 2.7 & 81.6 & 2.9 & 95 \\
\hline Y, ppm & 26.9 & 5.0 & 25 & -- & 107 \\
\hline $\mathrm{Yb}, \mathrm{ppm}$ & 2.7 & 17 & 2.7 & -- & 101 \\
\hline Zn, ppm & 353 & 5.4 & 350 & 4.8 & 101 \\
\hline
\end{tabular}

* $95 \%$ confidence interval

This table shows the results for seven analyses for SRM-2711 analyzed in-house in the USGS analytical laboratories in Denver, Co. 
TABLE A7 ICP-AES elements and their limits of determination

\begin{tabular}{|llll|}
\hline & & Total Digestion & $\mathrm{HCl} \mathrm{H2O}$ Leach \\
Element & $\mathrm{Symbol}$ & Procedure & Procedure \\
\hline \hline Aluminum & $\mathrm{Al}$ & $.005 \%$ & $30 \mathrm{ppm}$ \\
Calcium & $\mathrm{Ca}$ & $.005 \%$ & $30 \mathrm{ppm}$ \\
Iron & $\mathrm{Fe}$ & $.005 \%$ & $30 \mathrm{ppm}$ \\
Potassium & $\mathrm{K}$ & $.01 \%$ & $30 \mathrm{ppm}$ \\
Magnesium & $\mathrm{Mg}$ & $.005 \%$ & $30 \mathrm{ppm}$ \\
Sodium & $\mathrm{Na}$ & $.005 \%$ & $30 \mathrm{ppm}$ \\
Phosphorous & $\mathrm{P}$ & $.005 \%$ & $30 \mathrm{ppm}$ \\
Silicon & $\mathrm{Si}$ & -- & $30 \mathrm{ppm}$ \\
Titanium & $\mathrm{Ti}$ & $.005 \%$ & $30 \mathrm{ppm}$ \\
Manganese & $\mathrm{Mn}$ & $4 \mathrm{ppm}$ & $1.2 \mathrm{ppm}$ \\
Silver & $\mathrm{Ag}$ & $2 \mathrm{ppm}$ & $1.2 \mathrm{ppm}$ \\
Arsenic & $\mathrm{As}$ & $10 \mathrm{ppm}$ & $6 \mathrm{ppm}$ \\
Barium & $\mathrm{Ba}$ & $1 \mathrm{ppm}$ & $.6 \mathrm{ppm}$ \\
Cadmium & $\mathrm{Cd}$ & $2 \mathrm{ppm}$ & $1.2 \mathrm{ppm}$ \\
Cerium & $\mathrm{Ce}$ & $4 \mathrm{ppm}$ & $2.4 \mathrm{ppm}$ \\
Cobalt & $\mathrm{Co}$ & $1 \mathrm{ppm}$ & $.6 \mathrm{ppm}$ \\
Chromium & $\mathrm{Cr}$ & $1 \mathrm{ppm}$ & $.6 \mathrm{ppm}$ \\
Copper & $\mathrm{Cu}$ & $1 \mathrm{ppm}$ & $.6 \mathrm{ppm}$ \\
Gallium & $\mathrm{Ga}$ & $4 \mathrm{ppm}$ & -- \\
Lanthanum & $\mathrm{La}$ & $2 \mathrm{ppm}$ & $1.2 \mathrm{ppm}$ \\
Lithium & $\mathrm{Li}$ & $2 \mathrm{ppm}$ & $2 \mathrm{ppm}$ \\
Molybdenum & $\mathrm{Mo}$ & $2 \mathrm{ppm}$ & $1.2 \mathrm{ppm}$ \\
Niobium & $\mathrm{Nb}$ & $4 \mathrm{ppm}$ & -- \\
Neodymium & $\mathrm{Nd}$ & $4 \mathrm{ppm}$ & -- \\
Nickel & $\mathrm{Ni}$ & $2 \mathrm{ppm}$ & $1.2 \mathrm{ppm}$ \\
Lead & $\mathrm{Pb}$ & $4 \mathrm{ppm}$ & $2.4 \mathrm{ppm}$ \\
Antimony & $\mathrm{Sb}$ & -- & $3 \mathrm{ppm}$ \\
Scandium & $\mathrm{Sc}$ & $2 \mathrm{ppm}$ & -- \\
Strontium & $\mathrm{Sr}$ & $2 \mathrm{ppm}$ & $1.2 \mathrm{ppm}$ \\
Thorium & $\mathrm{Th}$ & $4 \mathrm{ppm}$ & $2 \mathrm{ppm}$ \\
Uranium & $\mathrm{U}$ & $100 \mathrm{ppm}$ & -- \\
Vanadium & $\mathrm{V}$ & $2 \mathrm{ppm}$ & $1.2 \mathrm{ppm}$ \\
Yttrium & $\mathrm{Y}$ & $2 \mathrm{ppm}$ & $1.2 \mathrm{ppm}$ \\
Ytterbium & $\mathrm{Yb}$ & $1 \mathrm{ppm}$ & -- \\
Zinc & $\mathrm{Zn}$ & $2 \mathrm{ppm}$ & $.6 \mathrm{ppm}$ \\
\hline & & & \\
\hline
\end{tabular}

